\title{
Perilaku Kepatuhan Perawat Melaksanakan SOP Terhadap Kejadian Keselamatan Pasien di Rumah Sakit X Kendari
}

\author{
Iriyanto Pagala*), Zahroh Shaluhiyah $^{* *}$, Baju Widjasena ${ }^{* *}$ \\ * Alumni Magister Promosi Kesehatan Universitas Diponegoro Semarang \\ Korespondensi : Pagalairiyanto@gmail.com \\ ** Magister Promosi Kesehatan Universitas Diponegoro \\ *** Bagian Promosi Keselamatan dan Kesehatan Kerja Fakultas Kesehatan Masyarakat \\ Universitas Diponegoro Semarang
}

\section{ABSTRAK}

Keselamatan pasien adalah pasien bebas dari cedera yang tidak seharusnya terjadi atau bebas dari cedera yang potensial akan terjadi (penyakit,cedera fisik/sosial psikologis, cacat, kematian) terkait dengan pelayanan kesehatan. Di Rumah Sakit X Kendari data kejadian keselamatan pasien pada tahun 2012 terdiri dari kesalahan dalam pemeriksaan laborat, pasien jatuh, salah pemberian seri kolf darah, pasien terbentur, salah dalam pemberian obat, kasus kematian pasien. Berdasarkan penentuan perioritas masalah yang akan di teliti yaitu pasien jatuh dari tempat tidur. Salah satu penyebabnya yaitu kurang patuhnya perawat dalam melaksanakan SOP resiko pasien jatuh. Tujuan penelitian ini adalah menganalisa faktor yang berhubungan antara karakteristik, pengetahuan, sikap, presepsi dukungan supervisior, presepsi dukungan sesama perawat, kenyamanan tempat/unit kerja dengan prilaku kepatuhan perawat dalam melaksanakan SOP resiko pasien jatuh terhadap terjadinya kejadian keselamatan pasien di Unit Rawat Inap Rumah Sakit X Kendari. Jenis penelitian yang digunakan adalah penelitian Explanatory Research dengan rancangan Cross sectional. Sampel dalam penelitian ini berjumlah 134 perawat ruang rawat inap. Hasil penelitian menunjukan terdapat 4 variabel yang berhubungan yaitu pengetahuan ( $p=$ $0,005)$, sikap $(p=0,035)$, persepsi dukungan supervisior $(p=0,000)$, persepsi dukungan sesama perawat $(p=0,003)$ dan faktor yang paling dominan berhubungan adalah persepsi dukungan supervisior $(O R=5,504)$.

Kata Kunci : Perawat, Kepatuhan Melaksanakan SOP

\section{ABSTRACT}

Compliance Behavior of Nurses Against Genesis SOP Implementing Patient Safety in Hospital X Kendari: The safety of patients were free of injury that is not supposed to happen or free from potential injury will occur (disease, physical injury / social psychological, disability, death) associated with health care. Hospital X Kendari patient safety event data in 2012 consisted of errors in laboratory examination, patient falls, one giving blood kolf series, patient knock, one in drug delivery, patient death cases. Based on the determination of the issues to be priorities in carefully which patients falling out of bed. One reason is lack of nurses in implementing SOP obedient, patient risk falling. The purpose of this study was to analyze factors related to the characteristics, knowledge, attitudes, perception supervisior support, perception of peer support nurse, comfort / unit with the behavior of nurses in implementing SOP compliance risk of the patient fell against the occurrence of patient safety in the Hospital Inpatient Unit X Kendari. This type of research is Explanatory Research research with cross sectional design. The sample in this study amounted to 134 inpatient room nurse. The results showed there were four variables related to that knowledge ( $p=$ $0.005)$, attitude $(p=0.035)$, perception of support supervisior $(p=0.000)$, perception of 
peer support nurses $(p=0.003)$ and the most dominant factor is the perception of support supervisior $(O R=5.504)$.

Keywords: Nurses, SOP Implement Compliance

\section{PENDAHULUAN}

Keselamatan pasien menjadi isu global yang paling penting saat ini dimana sekarang banyak dilaporkan tuntutan pasien atas medical error yang terjadi pada pasien. Keselamatan pasien rumah sakit adalah suatu sistem dimana rumah sakit membuat asuhan pasien lebih aman yang meliputi asesmen resiko, identifikasi dan pengelolaan hal yang berhubungan dengan resiko pasien, pelaporan dan analisis insiden, kemampuan belajar dari insiden dan tindak lanjutnya serta implementasi solusi untuk meminimalkan timbulnya resiko dan mencegah terjadinya cedera yang disebabkan oleh kesalahan akibat melaksanakan suatu tindakan atau tidak mengambil tindakan yang seharusnya diambil.

WHO menyebutkan bahwa ada beberapa faktor yang berhubungan dengan keselamatan pasien,

yaitu:

Organisational/managerial (budaya keselamatan, kepemimpinan, komunikasi), workgroup/team (struktur/proses kerja tim, pengawas), individual worker (kesadaran situasi, pengambilan keputusan, stres, kelelahan), work environment (lingkungan kerja yang berbahaya) (5). Leape , Dineen,
AHRQ, Depkes, Henrikson menyebutkan bahwa faktor-faktor yang berkontribusi terhadap terjadinya kejadian keselamatan pasien meliputi faktor karakteristik individu, sifat dasar pekerjaan, lingkungan fisik, interaksi antara sistem dan manusia, lingkungan organisasi dan sosial, manajemen, dan lingkungan eksternal.

IOM (Institute of Medicine) secara terbuka menyatakan bahwa paling sedikit 44.000 bahkan 98.000 pasien meninggal dirumah sakit dalam satu tahun akibat dari kesalahan medis (medical errors) yang sebetulnya bisa dicegah. Kemudian pada tahun 2000, IOM menerbitkan laporan "To Err is Human", Building a Safer Health System. Laporan itu mengemukakan penelitian di beberapa rumah sakit di Utah dan Colorado serta New York tentang KTD. Di Utah dan Colorado ditemukan KTD sebanyak 2,9\%, $6,6 \%$ diantaranya menyebabkan kematian, sementara di New York KTD sebesar 3,7\% dengan angka kematian mencapai $13,6 \%$. WHO pada tahun 2004 mengumpulkan angka-angka penelitian rumah sakit di berbagai negara: Amerika, Inggris, Denmark dan Australia, ditemukan KTD (Kejadian Tidak Diharapkan) dengan rentang 3,2-16,6\%. 
Data-data tersebut menjadikan pemicu berbagai negara untuk segera melakukan penelitian dan pengembangan Sistim Keselamatan pasien.

Laporan di atas telah menggerakkan sistem kesehatan dunia untuk merubah paradigma pelayanan kesehatan menuju keselamatan pasien (Patient safety). Gerakan ini berdampak juga terhadap pelayanan kesehatan di Indonesia melalui pembentukan KKP-RS (Komite Keselamatan Pasien Rumah Sakit) pada tahun 2004. Pada tahun 2007 KKP-RS melaporkan kejadian keselamatan pasien yaitu, sebanyak 145 insiden yang terdiri dari KTD 46\%, KNC 48\% dan lain-lain 6\% dan lokasi kejadian tersebut berdasarkan provisnsi ditemukan DKI jakarta 37,9\%, Jawa Tengah 15,9\%, Yogyakarta 13,8\%, Jawa Timur 11,7\%, Sumatra Selatan 6,9\%, Jawa Barat 2,8\%, Bali 1,4\%, Sulawesi selatan $0,69 \%$ dan Aceh $0,68 \%$. Berdasarkan laporan Peta Nasional Kejadian keselamatan pasien, Kesalahan dalam pemberian obat menduduki peringkat pertama $(24,8 \%)$ dari sepuluh besar insiden yang dilaporkan.

Salah satu rumah sakit yang telah menjalankan program Patient Safety adalah Rumah Sakit X. Rumah Sakit X adalah Rumah Sakit Tipe B yang menjadi salah satu pusat rujukan dari berbagai Pusat pelayanan kesehatan masyarakat. Sejak tahun 2008 Rumah Sakit $\mathrm{X}$ memiliki Komite
Keselamatan Pasien sebagai langkah awal dalam rangka perlindungan terhadap keselamatan pasien sekaligus sebagai antisipasi terhadap makin meningkatnya harapan pelanggaran terhadap pelayanan bermutu.

Data kejadian keselamatan pasien di Rumah Sakit X Tahun 2012 yaitu kejadian salah dalam pemeriksaan Laborat, sehingga pasien di periksa 2 kali (1 kasus), pasien jatuh dari tempat tidur (12 kasus), pasien jatuh di kamar mandi (3 kasus), salah dalam pemberian seri kolf darah, sehingga transfusi darah gagal dilakukan (1 kasus), pasien terbentur di mobil Ambulance sehingga pasien cedera (2 kasus), Salah dalam memberi obat (1 kasus), Kasus kematian pada pasien akibat keterlambatan penebusan resep (1 kasus). Wawancara yang dilakukan kepada ketua Komite Patient Safety Rumah Sakit X, kasus kejadian keselamatan pasien paling sering terjadi di unit ruang rawat inap, penyebabnya yaitu karena kurang patuhnya perawat terhadap SOP saat mengasuh pasien.

$$
\text { Sejak dideklarasikannya }
$$
pelaksanaan patient safety di Rumah Sakit X pada tahun 2008, masalah yang masih perlu diperhatikan yaitu kenyataan dilapangan yang merujuk pada konsep patient safety masih belum optimal, karena masih terjadi kasus pasien cedera, pasien jatuh, salah pengobatan, bahkan kematian terhadap pasien. Kenyataan ini menunjukkan praktik 
perawat yang kurang sempurna dalam menerapkan program keselamatan pasien di Rumah Sakit X Kendari. Berdasarkan jenis kejadian keselamatan pasien yang dipaparkan, karena keterbatasan penelitian dilakukan penentuan perioritas masalah yang akan di teliti dan yang menjadi perioritas masalah dalam penelitian ini yaitu kasus kejadian pasien jatuh dari tempat tidur. Sehingga dengan demikian yang menjadi rumusan masalah pada penelitian ini adalah faktor apa sajakah yang berhubungan dengan prilaku kepatuhan perawat dalam melaksanakan SOP resiko pasien jatuh terhadap terjadinya kejadian keselamatan pasien di Unit Rawat Inap Rumah Sakit X.

\section{METODE PENELITIAN}

Jenis penelitian yang digunakan dalam penelitian ini adalah penelitian penjelasan (Explanatory Research) yaitu penelitian yang akan menjelaskan hubungan antara variabel-variabel dalam penelitian melalui pengujian hipotesa. Rancangan penelitian yang digunakan adalah rancangan cross sectional yaitu suatu penelitian untuk mempelajari dinamika korelasi antara faktor-faktor resiko dengan efek, dengan cara pendekatan kuesioner dan observasi atau pengumpulan data sekaligus pada satu saat.
Populasi dalam penelitian adalah perawat bagian ruang rawat inap Rumah Sakit X Kendari. Kriteria kriteria inklusi responden yaitu perawat berusia $\geq 20$ tahun, pengalaman kerja $\geq 1$ tahun. Jumlah populasi dalam penelitian ini sebanyak 134 perawat dan pengambilan sampel dilakukan dengan metode total sampling. Lokasi penelitian dilaksanakan di Rumah Sakit X Kendari penelitan dilakukan selama satu bulan pada bulan Oktober tahun 2014. Variabel terdiri atas variabel terikat yaitu perilaku kepatuhan perawat melaksanakan SOP resiko pasien jatuh, dan variable bebas yaitu karakteristik perawat (umur, pendidikan, masa kerja, kompetensi), pengetahuan, sikap, presespsi dukungan supervisior, presepsi dukungan sesama perawat dan kenyamanan tempat/unit kerja. Instrumen yang digunakan untuk pengumpulan data yaitu dengan menggunakan kuesioner. Data yang diperoleh dari lapangan dikoreksi kebenarannya (editing) dan dikelompokkan, selanjutnya ditabulasi untuk dimasukkan dalam tebel analisis. Analisis yang dilakukan yaitu analisis univaria, bivariat dan multivariat dengan menggunakan aplikasi IBM SPSS statistic 20. 


\section{HASIL DAN PEMBAHASAN}

Berdasarkan hasil penelitian Karakteristik responden berdasarkan masa didapatkan bawah responden sebagian besar kerja diketahui bahwa sebagian besar (94\%) berusia Dewasa Muda (21-40 tahun) responden sudah memiliki masa kerja yang dan 6\% lainnya tergolong Dewasa Tua (41- lama ( $\geq 4$ Tahun) yaitu sebesar 64,9\% dan 60 tahun. Sementara itu berdasarkan tingkat kurang dari 4 tahun sebanyak 35,1\%. Hasil pendidikan didapatkan sebagian besar pengolahan data penelitian lainnya dapat responden memiliki pendidikan D3 dilihat pada table 1 berikut:

sebanyak $88,8 \%$ dan Sarjana 11,2\%.

Tabel 1. Hasil analisis statistik

\begin{tabular}{lcc}
\multicolumn{1}{c}{ Variabel } & $\mathrm{F}$ & $\%$ \\
\hline 1. Kompetensi & & \\
Kompetensi rendah (PK I,II) & 93 & 69,4 \\
Kompetensi tinggi (PK III, IV, V) & 41 & 30,6 \\
2. Pengetahuan perawat tentang SOP dan keselamatan pasien & & \\
- Pengetahuan kurang & 42 & 31,3 \\
- Pengetahuan baik & 92 & 68,7 \\
3. Sikap perawat dalam melaksanakan SOP & & \\
- Negatif & 30 & 22,4 \\
- Positif & 104 & 77,6 \\
4. Presepsi perawat mengenai dukungan supervisior & & \\
- Tidak mendukung & 44 & 32,8 \\
- Mendukung & 90 & 67,2 \\
5. Presepsi perawat mengenai dukungan sesama perawat & & \\
- Tidak mendukung & 67 & 50,0 \\
- Mendukung & 67 & 50,0 \\
6. Presepsi perawat mengenai kenyamanan tempat kerja & & \\
- Tidak nyaman & 22 & 16,4 \\
- Nyaman & 112 & 83,6 \\
7. Perilaku kepatuhan perawat melaksanakan SOP resiko pasien jatuh & & \\
- Tidak patuh & 81 & 60,4 \\
- Patuh & 53 & 39,6 \\
\hline
\end{tabular}


Tabel 2. Hasil analisis statistiki uji bivariat

\begin{tabular}{|c|c|c|c|c|c|c|c|c|}
\hline \multirow{3}{*}{ Variabel Bebas } & \multirow{3}{*}{ Kategori } & \multicolumn{6}{|c|}{$\begin{array}{c}\text { Variabel Terikat } \\
\text { Perilaku Kepatuhan Perawat } \\
\text { Melaksanakan SOP }\end{array}$} & \multirow{3}{*}{$\mathrm{P}$} \\
\hline & & \multicolumn{2}{|c|}{$\begin{array}{l}\text { Kurang } \\
\text { Patuh }\end{array}$} & \multicolumn{2}{|c|}{ Patuh } & \multicolumn{2}{|c|}{ Total } & \\
\hline & & $\mathrm{F}$ & $\%$ & $\mathrm{~F}$ & $\%$ & $\mathrm{~F}$ & $\%$ & \\
\hline \multirow[t]{2}{*}{ Umur } & Dewasa muda & 77 & 61,1 & 49 & 38,9 & 126 & 100 & \\
\hline & Dewasa Tua & 4 & 50,0 & 4 & 50,0 & 8 & 100 & 0,802 \\
\hline \multirow[t]{2}{*}{ Pendidikan } & DIII & 72 & 60,5 & 47 & 39,5 & 119 & 100 & \\
\hline & Sarjana & 9 & 60,0 & 6 & 40,0 & 15 & 100 & 1,000 \\
\hline \multirow[t]{2}{*}{ Masa Kerja } & Baru & 33 & 70,2 & 14 & 29,8 & 47 & 100 & \\
\hline & Lama & 48 & 55,2 & 39 & 44,8 & 87 & 100 & 0,130 \\
\hline \multirow[t]{2}{*}{ Kompetensi } & Rendah & 58 & 62,4 & 35 & 37,6 & 94 & 100 & \\
\hline & Tinggi & 23 & 56,1 & 18 & 43,9 & 41 & 100 & 0,623 \\
\hline \multirow[t]{2}{*}{ Pengetahuan } & Kurang & 33 & 78,6 & 9 & 21,4 & 42 & 100 & \\
\hline & Baik & 48 & 56,1 & 44 & 43,9 & 92 & 100 & 0,007 \\
\hline \multirow[t]{2}{*}{ Sikap } & Negatif & 24 & 77,4 & 7 & 22,6 & 31 & 100 & \\
\hline & Positif & 57 & 55,3 & 46 & 44,7 & 103 & 100 & 0,046 \\
\hline Dukungan & Tidak Mendukung & 37 & 84,1 & 7 & 15,9 & 44 & 100 & \\
\hline Supervisior & Mendukung & 44 & 48,9 & 46 & 51,1 & 90 & 100 & 0,000 \\
\hline \multirow{2}{*}{$\begin{array}{l}\text { Dukungan } \\
\text { sesama perawat }\end{array}$} & Tidak Mendukung & 49 & 73,1 & 18 & 26,9 & 67 & 100 & \\
\hline & Mendukung & 32 & 47,8 & 35 & 52,2 & 67 & 100 & 0,005 \\
\hline \multirow{2}{*}{$\begin{array}{l}\text { Kenyamanan } \\
\text { tempat kerja }\end{array}$} & Tidak nyaman & 15 & 68,2 & 7 & 31,8 & 22 & 100 & \multirow{2}{*}{0,567} \\
\hline & Nyaman & 66 & 58,9 & 46 & 41,1 & 112 & 100 & \\
\hline
\end{tabular}

Tabel 3. Hasil analisis statistiki uji multivariat

\begin{tabular}{cccccccccc}
\hline No & Variabel & B & S.E. & Wald & Df & Sig & Exp B & Lower & Upper \\
\hline 1 & Pengetahuan & 1,307 & 0,488 & 7,186 & 1 & 0,007 & 3,696 & 1.421 & 9,613 \\
2 & $\begin{array}{l}\text { Dukungan } \\
\text { Supervisior }\end{array}$ & 1,706 & 0,497 & 11,775 & 1 & 0,001 & 5,504 & 2,078 & 14.581 \\
& $\begin{array}{l}\text { Dukungan sesama } \\
\text { perawat }\end{array}$ & 1,298 & 0,422 & 9,451 & 1 & 0,002 & 3,663 & 1.601 & 8,379 \\
$\quad$ Constant & 4,048 & 0,819 & 24,423 & 1 & 0,000 & 0,017 & & \\
\hline
\end{tabular}


Kepatuhan perawat melaksanakan SOP resiko pasien jatuh

Frekuensi perilaku kepatuhan perawat dalam melaksanakan SOP resiko pasien jatuh lebih besar frekuensi perawat yang tidak patuh sebanyak $81 \quad(60,4 \%)$ perawat dibandingkan dengan frekuensi perilaku kepatuhan perawat dalam melaksanakan SOP resiko pasien jatuh yang patuh sebanyak $53(39,6 \%)$ perawat.

Kurang patuhnya perawat disebabkan karena masih kurangnya sosialisasi yang dilakukan pada perawat mengenai SOP resiko pasien jatuh, kemudian tidak tersedianya SOP mengenai resiko pasien jatuh di masing-masing unit rawat inap sehingga menyebabkan kurangnya pengetahuan perawat mengenai SOP resiko pasien jatuh. Disamping itu kurang patuhnya perawat dalam melaksanakan SOP resiko pasien jatuh karena kurangnya pengawasan oleh bagian keperawatan. Oleh sebab itu perlu adanya peningkatan program pelatihan atau sosialisasi khususnya mengenai pencegahan kejadian keselamatan pasien bagi tenaga keperawatan dan pelatihan mengenai mengasuh pasien yang beresiko jatuh sesuai SOP untuk. Selain itu perlu adanya pengawasan yang ketat sebagai langkah awal untuk mendisiplinkan perawat dalam kepatuhan perawat melaksanakan SOP resiko pasien jatuh dalam memberikan asuhan keperawatn pada setiap waktu dan kepada setiap pasien.

Kelman menjelaskan bahwa perubahan sikap dan perilaku individu diawali dengan proses patuh, identifikasi dan tahap terakhir berupa internalisasi. Pada awalnya individu mematuhi anjuran/instruksi tanpa kerelaan untuk melakukan tindakan tersebut dan seringkali karena ingin menghindari hukuman/sangsi jika dia tidak patuh, atau untuk memperoleh imbalan yang dijanjikan jika dia mematuhi anjuran tersebut. Tahap ini disebut tahap kepatuhan (compliance).

Biasanya perubahan yang terjadi pada tahap ini sifatnya sementara, artinya bahwa tindakan itu dilakukan selama masih ada pengawasan. Tetapi begitu pengawasan itu mengendur atau hilang, perilaku itupun ditinggalkan. Kepatuhan individu yang berdasarkan rasa terpaksa atau ketidakpahaman tentang pentingnya perilaku yang baru, dapat disusul dengan kepatuhan yang berbeda jenisnya, yaitu kepatuhan demi menjaga hubungan baik dengan tokoh yang menganjurkan perubahan tersebut.

\section{Karakteristik perawat berdasarkan} umur

Frekuensi pearawat berdasarkan
umur dalam penelitian ini lebih besar perawat yang berumur antara 21 - 40 tahun (dewasa muda) 126 (94\%) dibandingkan dengan perawat yang berumur antara $41-60$ 
tahun (dewasa tua) $8(6 \%)$. Hubungan antara umur perawat dengan perilaku kepatuhan perawat dalam melaksanakan SOP resiko pasien jatuh ditemukan bahwa perawat yang kurang patuh terhadap SOP resiko pasien jatuh lebih banyak terjadi pada kelompok umur dewasa muda $(61,1 \%)$ dibanding kelompok umur dewasa tua $(50,0)$. Pada variabel umur perawat dengan $p$ value $=0,802$ menunjukkan bahwa tidak ada hubungan yang signifikan antara umur perawat dengan prilaku kepatuhan perawat dalam melaksanakan SOP resiko pasien jatuh di Rumah Sakit X Kendari.

Hasil penelitian yang dilakukan oleh Suhartati tidak sesuai dalam penelitian ini bahwa ada hubungan antara umur perawat dengan perilaku perawat dalam melaksanakan SOP, terdapat kecenderungan semakin tua usia perawat semakin etik dalam melakukan asuhan keperawatan. Kenyataan ini akan membuatnya lebih berhati-hati dan memperhatikan secara seksama terhadap asuhan keperawatan yang ia lakukan.

Secara teori, umur berkaitan dengan tingkat kedewasaan dan maturasi, dalam arti meningkatnya umur akan meningkat pula kedewasaan/ kematangan secara teknis dan psikologis, serta semakin mampu melaksanakan tugasnya. Dalam usia 10 - 20 tahun, seseorang berada dalam tahap penjajakan. Dalm usia ini, mereka mulai menggali beberapa keahlian secara serius dan mulai mencoba untuk bekerja. Pada usia 25 - 44 tahun, seseorang berada dalam tahap pemantapan. Mereka secara terus menerus melakukan pengujian terhadap kemampuan yang dimiliki dan mencoba untuk melakukan pekerjaan yang sesuai dengan minat dan bakatnya.

Proporsi tertinggi usia perawat yang bekerja di Rumah Sakit X berumur antara 21 - 40 tahun, yaitu berada dalam tahap penjajakan dan pemantapan. Sehingga dengan meningkatnya prevalensi kejadian keselamatan pasien di Rumah Sakit X, maka usia perawat ini merupakan saat yang tepat untuk diarahkan dalam melakukan asuhan keperawatan harus sesuai dengan SOP.

\section{Karakteristik perawat berdasarkan pendidikan}

Frekuensi pearawat berdasarkan tingkat pendidikan lebih besar perawat yang berpendidikan DIII dibandingkan dengan perawat yang berpendidikan Sarjana. Sebanyak $119(88,8 \%)$ perawat yang berpendidikan DIII dan 15 (11,2\%) perawat yang berpendidikan Sarjana. Hasil analisis mengenai hubungan antara pendidikan perawat dengan perilaku kepatuhan perawat dalam melaksanakan SOP resiko pasien jatuh ditemukan bahwa perawat yang kurang patuh terhadap SOP resiko pasien jatuh lebih banyak terjadi pada perawat yang memiliki tingkat pendidikan DIII (60,5\%) dibanding perawat yang memiliki tingkat pendidikan Sarjana $(60,0 \%)$. Pada variabel ini diketehui 
nilai $\mathrm{p}$ value $=1,000$ menunjukkan bahwa tidak ada hubungan yang signifikan antara tingkat pendidikan perawat dengan prilaku kepatuhan perawat dalam melaksanakan SOP resiko pasien jatuh di Rumah Sakit X Kendari.

Frekuensi tingkat pendidikan di Rmah Sakit X lebih banyak perawat dengan tingkat pendidikan DIII. Hal ini disebabkan karena ada keharusan sesuai Permenkes No. 1239 tahun 2001, mengenai registrasi dan praktek perawat. Oleh karena itu dapat dipahami bahwa tingkat pendidikan tenaga perawat di Rumah Sakit X lebih besar adalah DIII Keperawatan. Hasil penelitian yang dilakukan oleh Anugrahini mengungkapkan ada hubungan yang signifikan antara pendidikan dengan kepatuhan perawat dalam menerapkan pedoman patient safety di RSAB Harapan Kita Jakarta. Namun demikian, hal tersebut tidak terbukti pada penelitian ini. Hal ini bisa disebabkan karena pendidikan perawat pelaksana di Rumah Sakit X hampir seragam, yakni merupakan lulusan D3. Tetapi dalam bekerja tidak hanya pendidikan formal saja yang harus dimiliki oleh perawat melainkan harus dilengkapi dengan berbagai pelatihanpelatihan yang mendukung terhadap pekerjaan yang tidak didapatkan selama menjalankan pendidikan.

Pendidikan yaitu proses formal dari pelatihan seorang intelek dan suatu pengembangan seseorang yang meliputi intelektual, spiritual, moral, kreatif, emosional dan juga kegiatan fisik. Menurut Green tingkat pendidikan merupakan faktor predisposisi seseorang untuk berprilaku sehingga latar belakang pendidikan merupakan faktor yang mendasar dan memotivasi terhadap perilaku atau yang memberikan referensi pribadi dalam pengalaman belajar seseorang.

\section{Karakteristik perawat menurut masa}

\section{kerja}

Frekuensi pearawat berdasarkan masa kerja pada penelitian ini lebih besar perawat yang memiliki masa kerja lama 87 $(64,9 \%)$ dibandingkan dengan perawat yang memiliki masa kerja baru 47 (35,1\%). Hasil analisis antara hubungan masa kerja dengan perilaku kepatuhan perawat dalam melaksanakan SOP menunjukkan bahwa perawat yang kurang patuh terhadap SOP resiko pasien jatuh lebih banyak terjadi pada perawat yang memiliki masa kerja baru $(70,2 \%)$ dibanding perawat yang memiliki masa kerja lama $(55,2 \%)$. Variabel ini juga menunjukkan bahwa tidak ada hubungan yang signifikan antara masa kerja perawat dengan prilaku kepatuhan perawat dalam melaksanakan SOP resiko pasien jatuh dengan nilai $p$ value $=0,130$.

Masa kerja berkaitan dengan pengalaman seseorang, dan pengalaman sangat dibutuhkan dalam melakukan asuhan keperawatan kepada pasien. Pengalaman kerja yang dimiliki oleh perawat akan 
memberikan kemampuan berupa menunjangnya dalam bekerja. Dengan pengetahuan, keterampilan, dan tingkah pengalaman kerja yang lebih lama tentunya laku pada perawat tersebut yang perawat akan memiliki pengalaman yang menunjangnya dalam bekerja. Dengan lebih lama pula dalam menangani pasien Pengalaman kerja yang lebih lama tentunya dengan berbagai permasalahan yang perawat akan memiliki pengalaman yang dihadapinya. Selain karena pengalaman lebih lama pula dalam menangani pasien dengan berbagai permasalahan yang yang telah banyak dimiliki, Pengalaman dihadapinya. Selain karena pengalaman yang telah banyak dimiliki, Pengalaman kerja juga membuat perawat pelaksana lebih terampil dan berhati-hati agar asuhan keperawatan yang dilakukan tidak menimbulkan cedera bagi pasien.

Hasil penelitian ini tidak sejalan dengan penelitian yang dilakukan oleh Nurwidia pengalaman kerja menjadi salah satu faktor kunci dalam perilaku terhadap keselamatan pasien di rumah sakit. Pengalaman kerja menjadi faktor yang berhubungan secara siginifikan pada kejadian keselamatan pasien karena ada kecenderungan dimana perawat yang telah bekerja lama di rumah sakit memiliki kemampuan lebih baik dalam melakukan asuhan keperawatan yang aman bagi pasien.

Pengalaman kerja berkaitan dengan pengalaman seseorang, dan pengalaman sangat dibutuhkan dalam melakukan asuhan keperawatan kepada pasien. Pengalaman kerja yang dimiliki oleh perawat akan memberikan kemampuan berupa pengetahuan, keterampilan, dan tingkah laku pada perawat tersebut yang

\section{Karakteristik perawat berdasarkan kompetensi}

Frekuensi pearawat berdasarkan tingkat kompetensi pada penelitian ini lebih besar perawat yang memiliki kompetensi rendah $93(69,4 \%)$ dibandingkan dengan perawat yang memiliki kompetensi tinggi 41 $(30,6 \%)$. Kemudian berdasarkan hasil analisis hubungan antara kompetensi perawat dengan perilaku kepatuhan perawat dalam melaksanakan SOP menunjukkan bahwa perawat yang kurang patuh terhadap SOP resiko pasien jatuh lebih banyak terjadi pada perawat yang memiliki tingkat kompetensi rendah $(62,4 \%)$ dibanding perawat yang memiliki tingkat kompetensi tinggi $(56,1 \%)$. Pada variabel ini 
menunjukkan bahwa tidak ada hubungan yang signifikan antara kompetensi perawat dengan prilaku kepatuhan perawat dalam melaksanakan SOP resiko pasien jatuh di Rumah Sakit X Kendari.

Kompetensi yang dimaksud pada penelitian ini adalah tingkat kemampuan perawat dengan tingkat pendidikan tertentu setelah melalui Pengalaman kerjadan berbagai pelatihan, jadi kompetensi lebih kearah skill perawat yang difokuskan hanya untuk perawat professional klinik. Perawat professional adalah perawat dengan latar belakang pendidikan tinggi, minimal D3 keperawatan, sementara perawat klinik adalah perawat yang memberikan asuhan keperawatan langsung kepada pasien/klien. Sehingga yang termasuk kedalam kelompok kompetansi keperawatan adalah perawat dengan pendidikan minimal D3 yang memberikan pelayanan langsung kepada pasien/klien.

Sistem jenjang kompetensi yang disusun dan dijalankan oleh Komite Keperawatan Rumah Sakit ' $X$ ' ini dinilai dari pendidikan, masa kerja, performa yang ditunjukkan pada saat menjalankan asuhan keperawatan serta banyaknya pelatihan yang sudah diikuti perawat tersebut. Hal yang demikian bisa menjadi pengaruh yang kuat dalam menentukkan baik tidaknya seseorang dalam menjalankan asuhan keperawatan, termasuk bagaimana perawat tersebut melakukan asuhan keperawatan yang aman dan tidak menyebabkan kejadian keselamatan pasien. Penelitian yang dilakukan oleh Dede Srimulyana tidak sejalan dengan penelitian ini dimana menunjukkan bahwa tingkat kompetensi perawat memiliki hubungan yang signifikan dengan terjadinya kejadian keselamatan pasien di Rumah Sakit X. Pada hasil statistik juga menunjukkan nilai OR sebesar 2,9 yang dapat diartikan bahwa responden, dalam hal ini perawat, yang berkompetensi rendah memiliki kecenderungan 3 (tiga) kali lebih besar dari yang berkompetensi tinggi untuk menyebabkan kejadian keselamatan pasien.

\section{Pengetahuan perawat tentang kejadian keselamatan pasien dan SOP resiko pasien jatuh}

Pengetahuan perawat pada penelitian ini menunjukkan bahwa pengetahuan perawat lebih banyak yang memiliki pengetahuan baik sebanyak 92 perawat $(68,7 \%)$ dibandingkan dengan yang memiliki pengetahuan kurang sebanyak 42 perawat $(45,3 \%)$. Hal tersebut menunjukkan bahwa tingkat pengetahuan perawat mengenai kejadian keselamatan pasien dan SOP resiko pasien jatuh belum sepenuhnya baik. Hasil analisis antara hubungan pengetahuan perawat dengan perilaku kepatuhan perawat dalam melaksanakan SOP menunjukkan bahwa perawat yang kurang patuh terhadap SOP resiko pasien jatuh lebih banyak terjadi pada perawat yang memiliki pengetahuan kurang sebanyak 
$78,6 \%$ dibanding perawat yang memiliki tingkat pengetahuan baik sebanyak $56,1 \%$. Pada variabel ini menunjukkan ada hubungan yang signifikan antara pengetahuan perawat dengan prilaku kepatuhan perawat dalam melaksanakan SOP resiko pasien jatuh di Rumah Sakit X Kendari dengan nilai $\mathrm{p}$ value $=0,007$. Penelitian ini menunjukkan bahwa pengetahuan perawat tentang kejadian keselamatan pasien dan SOP resiko pasien jatuh yang baik mempunyai peluang 3 kali lebih patuh dalam melaksanakan SOP resiko pasien jatuh dibanding perawat yang memiliki pengetahuan kurang.

Perawat yang mempunyai pengetahuan baik pada penelitian ini ternyata sebagian besar masih kurang patuh dalam melaksanakan SOP resiko pasien jatuh. Hasil tersebut memperlihatkan bahwa bertambahnya pengetahuan seseorang tidak selalu diikuti oleh perubahan perilaku. Menurut Green, menyebutkan bahwa peningkatan pengetahuan tidak selalu menyebabkan perubahan perilaku. Pengetahuan merupakan faktor penting namun tidak memadahi dalam perubahan perilaku kesehatan.

Penelitian yang dilalukan oleh Teguh Kuncoro menunjukkan hasil yang sama dengan penelitian ini bahwa ada hubungan yang signifikan antara pengetahuan perawat dengan kepatuhan melaksanakan SOP dalam mengasuh pasien terhadap upaya pencegahan kejadian keselamatan pasien. Disampimping itu hasil penelitian ini juga sesuai dengan penelitian yang dilakukan oleh Henriksen dimana ada hubungan yang signifikan antara pengetahuan perawat dengan penyebab terjadinya kejadian keselamatan pasien.

Sikap perawat dalam melaksanakan SOP resiko pasien jatuh

Sikap perawat pada penelitian ini menunjukkan bahwa sikap responden lebih banyak yang memiliki sikap positif sebanyak 104 perawat $(77,6 \%)$ dibandingkan dengan yang memiliki sikap negatif sebanyak 30 perawat $(22,4 \%)$. Namun dengan demikian menunjukkan bahwa sikap responden dalam melaksanakan SOP resiko pasien jatuh belum sepenuhnya baik, hal tersebut terjadi karena sebagian perawat masih memiliki pengetahuan dasar yang kurang khususnya mengenai SOP resiko pasien jatuh dan kurangnya pengawasan kepada perawat dalam mengasuh pasien.

Hasil analisis hubungan antara sikap perawat dengan kepatuhan perawat dalam melaksanakan SOP resiko pasien jatuh menunjukkan bahwa perawat yang kurang patuh terhadap SOP resiko pasien jatuh lebih banyak terjadi pada perawat yang memiliki sikap negatif sebanyak $77,4 \%$ dibanding perawat yang memiliki sikap positif sebanyak 55,3\%. Hasil penelitian ini menunjukkan ada hubungan yang signifikan 
antara sikap perawat dengan prilaku kepatuhan perawat dalam melaksanakan SOP resiko pasien jatuh dengan nilai $p$ value $=0,046$.

Penelitian ini sesuai dengan penelitian yang dilakukan Yuliastuti dengan hasil penelitian bahwa sikap berpengaruh terhadap kepatuhan perawat dalam pemasangan infus sesuai SOP. Penelitian ini didukung oleh Gibson mengemukakan bahwa sikap merupakan faktor penentu perilaku. Berupa kesiapaan kesiapsiagaan mental, yang dipelajari pada satu periode waktu dan diorganisasikan oleh pengalaman, dan mempunyai pengaruh tertentu atas cara tanggap seseorang terhadap orang lain, objek, dan situasi yang berhubungan dengannya. Sikap ditentukan oleh tiga komponen yaitu kognitif, afeksi dan perilaku.

Keadaan ini menunjukkan bahwa sikap perawat dalam hal ini tidak berakhir pada terbentuknya sebuah perilaku, artinya dengan sikap positif yang dimiliki petugas tidak selamanya direalisasikan dalam bentuk perilaku yang positif. Hal ini sebagai mana teori yang dituliskan oleh Walgito, menyatakan sikap sebagai faktor yang ada pada diri manusia dan dapat menyebabkan kecendrungan manusia untuk berbuat atau bertingkah laku terhadap obyek yang dihadapi.

\section{Persepsi perawat mengenai dukungan supervisior}

Hasil penelitian menunjukkan bahwa presepsi perawat terhadap dukungan supervisior lebih banyak yang memiliki presepsi dukungan supervisior mendukung sebanyak $90(67,5 \%)$ perawat dibandingkan dengan yang memiliki presepsi dukungan supervisior tidak mendukung sebanyak 44 $(32,8 \%)$ perawat. Namun dengan demikian menunjukkan bahwa presepsi perawat mengenai dukungan supervisior belum sebenuhnya mendukung.

Hasil analisis hubungan antara presepsi perawat mengenai dukungan supevisior dengan perilaku kepatuhan perawat dalam melaksanakan SOP menunjukkan bahwa perawat yang kurang patuh terhadap SOP resiko pasien jatuh lebih banyak terjadi pada perawat yang memiliki presepsi supervisior tidak mendukung sebanyak $84,1 \%$ dibanding perawat yang memiliki presepsi supervisior mendukung sebanyak 48,9\%. Hasil analisis hubungan antara peresepsi perawat mengenai dukungan supervisior dengan perilaku kepatuhan perawat dalam melaksanakan SOP resiko pasien jatuh menunjukkan bahwa ada hubungan yang signifikan antara dukungan supervisior dengan prilaku kepatuhan perawat dalam melaksanakan SOP resiko pasien jatuh dengan nilai $p$ value $=0,000$. Setelah dilakukan uji statistik multivariat menunjukkan bahwa variabel 
persepsi dukungan supervisior yang paling dominan sebagai prediktor terjadinya perilaku kepatuhan perawat dalam melaksanakan SOP resiko pasien jatuh dengan nilai adjusted OR atau $\operatorname{Exp}(\mathrm{B})=$ 5,504. Hal ini berarti bahwa persepsi perawat terhadap dukungan supervisior yang mendukung mempunyai peluang $5 \mathrm{kali}$ lebih patuh dalam melaksanakan SOP resiko pasien jatuh dibanding perawat yang memiliki persepsi supervisior tidak mendukung.

Persepsi akan sesuatu dapat saja berubah-ubah maknanya walaupun realitasnya sama saja. Adanya faktor situasi dan faktor target yang dapat mempengaruhi persepsi seseorang terhadap obyek. Persepsi juga sangat tergantung pada karakteritik individual seperti sikap, motivasi, kepentingan, pengalaman, dan harapan. Jika kita ingin merubah perilaku tidak aman seseorang, kita harus menyamakan persepsi dahulu. Hal ini sesuai bahwa perilaku seseorang ditentukan oleh apa yang dirasakan daripada risiko yang sebenarnya. Dukungan adalah suatu kondisi dimana seseorang diberi dorongan sehingga merasa aman dan nyaman secara psikologis, termasuk di dalamnya kesadaran dari keberadaan yang baik dan kepuasan dari affect hunger (senang akan keinginan besar).

Supervisor memiliki tanggung jawab besar dalam organisasi/perusahaan, karena supervisor adalah orang yang secara langsung berhubungan dengan anggota kelompoknya. Mereka memimpin, mengelola, menegur, mengarahkan, memberi contoh, berkomunikasi dan memotivasi. Kepemimpinan dan komunikasi merupakan keterampilan utama yang harus dimiliki oleh seorang supervisor. Supervisior harus mampu menciptakan lingkungan yang mendukung komunikasi efektif, merangsang kreativitas dan motivasi. Supervisior mengusahakan seoptimal mungkin kondisi kerja yang kondusif dan nyaman yang mencakup lingkungan fisik, atmosfer kerja, dan jumlah sumber sumber yang dibutuhkan untuk memudahkan pelaksanaan tugas.

\section{Persepsi perawat mengenai dukungan sesama perawat}

Hasil penelitian menunjukkan bahwa presepsi perawat terhadap dukungan sesama perawat sama besar dimana perawat yang memiliki presepsi dukungan sesama perawat mendukung sebanyak $67(50,0 \%)$ perawat. Kemudian perawat yang memiliki presepsi dukungan supervisior tidak mendukung sebanyak $67(50,0 \%)$ perawat. Kenyataan tesebut menunjukkan bahwa sebagian besar memiliki presepsi masih kurang mendukung dalam hal mengasuh pasien. Hasil analisis hubungan antara peresepsi dukungan sesama perawat dengan perilaku kepatuhan dalam melaksanakan SOP menunjukkan bahwa perawat yang kurang patuh terhadap 
SOP resiko pasien jatuh lebih banyak terjadi pada perawat yang memiliki presepsi rekan perawat tidak mendukung sebanyak $73,1 \%$ dibanding perawat yang memiliki presepsi rekan perawat mendukung sebanyak $47,8 \%$. Pada variabel ini menunjukkan bahwa ada hubungan yang signifikan antara dukungan sesama perawat dengan prilaku kepatuhan perawat dalam melaksanakan SOP resiko pasien jatuh di Rumah Sakit X Kendari dengan nilai $\mathrm{p}$ value $=0,005$.

Hasil penelitian ini juga menunjukkan bahwa bahwa persepsi perawat terhadap dukungan sesama perawat yang mendukung mempunyai peluang 3 kali lebih patuh dalam melaksanakan SOP resiko pasien jatuh dibanding perawat yang memiliki persepsi dukungan sesama perawat tidak mendukung. Persepsi dukungan sesama perawat sebagian besar masih kurang mendukung hal tersebut terjadi disebabkan karena masih adanya kelompok - kelompok kecil dalam bergaul, misalnya para perawat hanya bergaul dengan perawat yang seusianya atau sebaya, antara perawat yang sudah bekerja lama dan yang masih baru, terjadi kesukaran untuk bertanya dalam hal mengasuh pasien, perawat yang merasa lebih tua merasa gengsi bertanya kepada perawat yang berusia lebih muda, kemudian perawat yang lebih muda merasa segan bertanya kepada perawat yang lebih tua. Kenyataan tersebut menyebabkan terjadinya komunikasi yang kurang begitu baik. Hal ini sesuai dengan jawaban perawat menyatakan bahwa rekan kerja perawat di ruangan tidak mampu menciptakan komunikasi yang baik dalam mendorong untuk memberikan pelayanan yang terbaik kepada pasien dan juga menyatakan rekan kerja perawat di ruangan tidak bersedia bertukar informasi mengenai SOP resiko pasien jatuh.

Penelitian ini sesuai dengan penelitian yang dilakukan Yuliastuti dengan hasil penelitian bahwa dukungan rekan kerja mempunyai pengaruh yang signifiakn terhadap kepatuhan perawat dalam pemasangan infus sesuai SOP. Persepsi seseorang terhadap suatu objek dapat berbeda-beda. Demikian pula persepsi seorang perawat terhadap konflik peran dapat berbeda-beda. Apabila konflik peran dirasakan sebagai sebuah proses pembelajaran ditengah pertentangan maka perawat akan mempunyai persepsi yang positif terhadap konfllik peran. Namun, apabila karyawan menganggap konflik peran tersebut sebagai suatu kesulitan yang akan mengg anggunya dalam bekerja sehingga karyawan merasa tertekan dan tidak produktif dalam bekerja maka konflik peran tersebut akan dipersepsi negatif.

\section{Kenyamanan tempat/unit kerja}

Variable lain yang terkait dengan kejadian keselamatan pasien adalah faktor lingkungan fisik yang meliputi: pencahayaan, tingkat kebisingan, 
temperature atau suhu ruangan, susunan tata ruang, dan ventilasi. Pengelolaan gedung rumah sakit harus benar-benar memikirkan standar keselamatan baik bagi pasien maupun keselamatan staf dengan memperhatikan syarat-syarat kesehatan lingkungan seperti yang sudah diatur di dalam Permenkes nomor 1204/SK/X/2004 tentang Persyaratan Kesehatan Lingkungan Rumah Sakit. Hasil penelitian menunjukkan bahwa frekuensi kenyamanan tempat/unit kerja lebih besar yang menyatakan bahwa kenyamanan tempat/unit kerja dalam kategori nyaman sebanyak $112(83,6 \%)$ perawat dibandingkan dengan yang menyatakan tempat/unit kerja dalam kategori tidak nyaman sebanyak $22(16,4 \%)$ perawat.

Uji hubungan antara kenyamanan tempat/unit dengan perilaku kepatuhan perawat dalam melaksanakan SOP resiko pasien jatuh menunjukkan bahwa perawat yang kurang patuh terhadap SOP resiko pasien jatuh lebih banyak terjadi pada perawat yang memiliki presepsi tidak nyaman sebanyak $68,2 \%$ dibanding perawat yang memiliki presepsi nyaman sebanyak $58,9 \%$. Pada variabel ini didapatkan nilai $\mathrm{p}$ value $=0,567$ yang berarti tidak ada hubungan yang signifikan antara dukungan sesama perawat dengan prilaku kepatuhan perawat dalam melaksanakan SOP resiko pasien jatuh.
Melihat distribusi jumlah perawat berdasarkan persepsi terhadap kenyamanan tempat kerja, sebagian besar juga memiliki persepsi kurang baik terhadap kenyamanan tempat kerja, Meski demikian, kenyamanan tempat kerja tetap tidak cukup menjadi faktor penentu terlaksananya perilaku kepatuhan perawat dalam melaksanakan SOP resiko pasien jatuh terhadap terjadinya kejadian keselamatan pasien. Kondisi setiap ruang perawatan di Rumah Sakit ' $X$ ' ini berbeda-beda, ada yang telah selesai tahap pembangunannya sehingga perawat merasa sudah nyaman tetapi ada pula yang masih dalam kondisi penyelesaian atau perampungan dimana sistem pendingin udara/AC ruangan dan ventilasi udara sebagian masih dalam tahap penyelesaian yang menyebabkan ruang perawatan dirasa kurang mendukung bagi perawat pelaksana, terutama bagi perawat dengan pengalaman kerja baru.

Penelitian yang dilakukan oleh Hendriksen tidak sesuai dengan penelitian ini dimana hasil penelitian lain yang dilakukan menunjukkan bahwa ada hubungan yang signifikan antara kenyamanan tempat/unit kerja dengan penyebab terjadinya kejadian keselamatan pasien. 


\section{Kepustakaan}

Depkes. 2008. Panduan Nasional Keselamatan Pasien Rumah Sakit. KKPRS. Jakarta.

Depkes. 2011. Peraturan Menteri Kesehatan Republik Indonesia No.1691/Menkes/Per/VIII/2011, tentang Keselamatan Pasien Rumah sakit. Jakarta

Direktorat Bina pelayanan Keperawatan. 2008. Pedoman Indikator Mutu Pelayanan Keperawatan Klinik. Direktorat Bina Pelayanan Keperawatan. Jakarta

Fitri, L. 2010. Pengaruh pengetahuan, sikap dan keterampilan perawat terhadap keselamatan pasien di RSU $\mathrm{H}$. Sahudin Kutacane. Tesis. USU

Green, Lawrence W. 2000. Health Education Planning, A Diagnostic Approach. Mayfield Publishing Company. California

Hughes, R.G., \& Clancy, M.C. 2005 Working Conditions that support patient safety. J Nurs Care Qual. Vol.20, No.4, pp 289-292

Hendriksen, K. 2008. Patient Safety and Quality: an avidence base handbook for nurses. Rockville MD: Agency for Health Care Research and Quality Publications.

Joint Commision International. 2011.

Standar Akreditasi Rumah Sakit, Suizer, A,B. 1999. Safety behavior: fewer Injuries?. Balai Pustaka. Jakarta

Enam Sasaran Keselamatan pasien. Edisi ke-4. Jakarta

J.R. Reason. 1990. Human Error. Cambridge University press. Newyork

Linda T. Kohn, Janet M. Corrigan, and Molla S.Donaldson . 2000. To Err Is Human : Building a Safer Health System. National Academy Press. Washington DC.

Notoatmodjo S. 2012. Metodologi Penelitian Kesehatan. Rineka Cipta. Jakarta

Prawitasari, S. 2009. Hubungan Beban Kerja Perawat Pelaksana dengan Keselamatan Pasien di Rumah Sakit Husada Jakarta. Tesis FIK UI. Jakarta Reason J. 2000. Human Error: modes and management. BMJ. Newyork

World Health Organization. 2009. Human Factors in Patient Safety : Review of Topics and Tools. Word Health Organization. Geneva

Srimulyana, D. 2013. Faktor yang berhubungan dengan kejadian keselamatan pasien di Rumah Sakit X. FIK UI. Jakarta

Suhartati. 2010. Analisis pengaruh karakteristik, pengetahuan dan sikap perawat dalam melaksanakan SPO Universal pasca operasi di Rumah Sakit X. Tesis FIK UI. Jakarta 